\title{
Cobblestone Area-Forming Cells
}

National Cancer Institute

\section{Source}

National Cancer Institute. Cobblestone Area-Forming Cells. NCI Thesaurus. Code

C113240.

The number of hematopoietic stem cells (HSCs) that migrate between or beneath a cocultured feeder cell layer and become trapped. When HSCs are cultured with a feeder layer and observed using phase contrast microscopy, the trapped cells appear less spherical and less refractile than the HSCs that are floating loosely on top of the feeder layer. 